\title{
RELIABILITY ANALYSIS OF CRITICAL KINEMATIC PAIR OF THE RD-33 ENGINE
}

\section{Analiza wytrzymałościowa krytycznej pary kinematycznej silnika RD-33}

\begin{abstract}
The article addressed the technological problem occurring in the RD-33 turbine engine on the kinematic pair between the accessory gearbox (AGB) and fuel regulator pump HP-59A (Polish: NR-59A). In the beginning, examples of operational problems were described. Then, the power balance for the accessory gearbox and strength calculations of gear and splines of a critical pair were presented. It was demonstrated that gear made from an original material complies with strength criteria and the observed operational problems with splines are created by other factors.
\end{abstract}

Keywords: aviation, reliability, analysis, strength, power, gear

Streszczenie: $W$ artykule przedstawiono problem technologiczny wystęujacy $w$ silniku turbinowym RD-33 na połaczeniu kinematycznym między skrzynka napędu agregatów a pompa regulatora paliwa HP-59A. Na poczatku opisano przyktadowe problemy eksploatacyjne, następnie przedstawiono bilans mocy dla skrzynki napędu agregatów i obliczenia wytrzymałościowe dla koła zębatego i wielowypustu krytycznego połaczenia. Wykazano, że koło zębate wykonane $z$ oryginalnego materiału spetnia warunki wytrzymałościowe, natomiast obserwowane problemy eksploatacyjne z wielowypustem sa generowane przez inne czynniki.

Słowa kluczowe: lotnictwo, niezawodność, analiza, wytrzymałość, moc, koło zębate 


\section{Introduction}

At the end of the " 60 s of the XX century, on the territory of the former USSR commenced the works on the third generation of fighter aircraft. The newly designed fighter MiG-29 was aimed to form a counterbalance to the F-15 of the US army. In 1971, first official requirements for the new aircraft were developed, and its configuration was similar to that of MiG-25. During the next 4 years, the design intents were still changing. On 6 October 1977, the first test flight of a prototype was performed [20]. National tests of MiG-29 were completed in 1983, and the production of the first batch started. The fighter, equipped with two by-pass turbojets RD-33, was included in the weaponry of the Soviet army in 1987 [20]. A year later, its first demonstration abroad took place on the air show in Farnborough (UK) [18]. In 1989, MiG-29 aircraft was implemented in the Polish military aviation (currently the Air Force of the Republic of Poland), where until now it is used by two military units in Poland and foreign missions [17].

MiG-29 aircraft has introduced new operational problems with their engines, having an impact on flight safety. The most critical place in the RD-33 engine, due to its structure (fig. 1) and the principle of operation [14], are vanes of the high and low-pressure compressor. The problem is caused by the ingestion of foreign objects into the engine, which results in mechanical damage of vane, change of the distribution of mass forces, unbalancing of rotor and increase in engine vibrations. As a result, there is a risk to break the vane due to wearing and in some situations, seizure of the rotor shaft [15]. Other sources of foreign objects getting to the engine were the falling rivets of the upper air inlet [12].

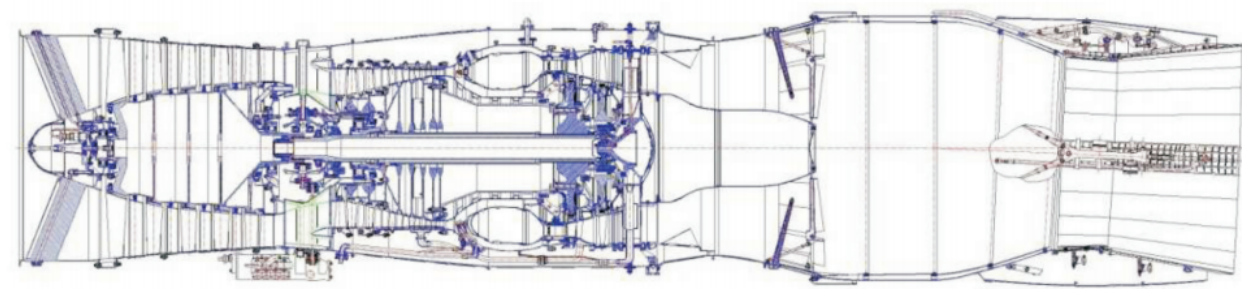

Fig. 1. Cross-section of the RD-33 engine [5]

Turbine vanes demonstrate overheating of the leading edge and hightemperature corrosion, which is due to [1]:

a) applied design solution of the afterburner initiation,

b) applied protective coatings of vanes,

c) change of the fuel type from PSM-2 to F-34 (used in NATO) [6], 
d) change of the distribution of the thermal field of exhaust gases in front of the turbine,

e) occasional regulation errors of the engine fuel system.

The examples of damage to the turbine vanes, detected during scheduled nondestructive testing, were illustrated in fig. 2 [1].
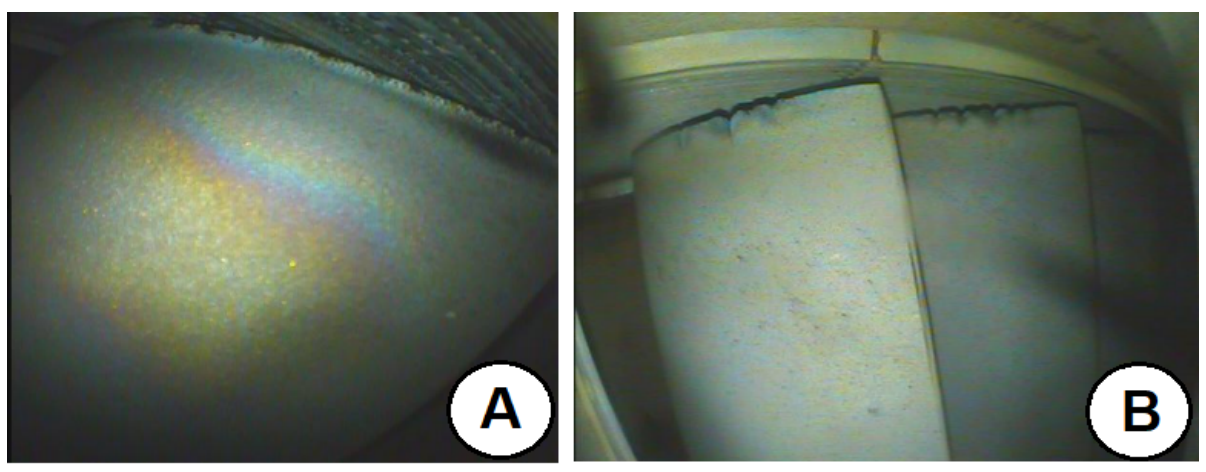

Fig. 2. Examples of damage to the vanes of the high-pressure turbine [1] (A - discoloration, $\mathrm{B}$ - cracks)

A serious operational problem in RD-33 engines is graphite seals in the rear support. The seals are made of graphite with brittleness between 1 and 2 in the Mohs scale (approx. $40 \mathrm{HV}$ ) [4]. Due to the increased engine vibrations, there are scratches and micro-cracks on the sealing surface, which deteriorate the quality of sealing and result in leaking. A negative impact on bearings of the rotor shaft is also exerted by dynamic loads and vibrations occurring in the operation of highpressure and low-pressure turbine vanes [15].

For a few years, RD-33 engines used in the Polish Air Force experience also a problem of the accelerated fatigue degradation of a kinematic pair of the accessory gearbox (AGB) with fuel regulator pump NR-59A. The attention in this article was focused on this particular problem, presenting the selected results of strength analysis.

\section{Test object}

The most critical place in AGB (fig.3) is a gear of the drive of fuel regulator pump NR-59A, the geometry and design parameters of which are presented in Fig.4. The original gear was made from steel 12H2NWFA-WD, for which the permissible bending stresses are in the range from $30 \mathrm{HRC}$ to $40 \mathrm{HRC}$ [5]. The 
basic reasons for the lack of such gear in the overhaul of the RD-33 engine (based on the documentation of WZL) are as follows:

- excessive traces of abrasion,

- corrosion or fretting on the splines mating with the shaft,

- pitting,

- micro-cracks on the working surface of gear teeth,

- traces of discoloration due to overheating.

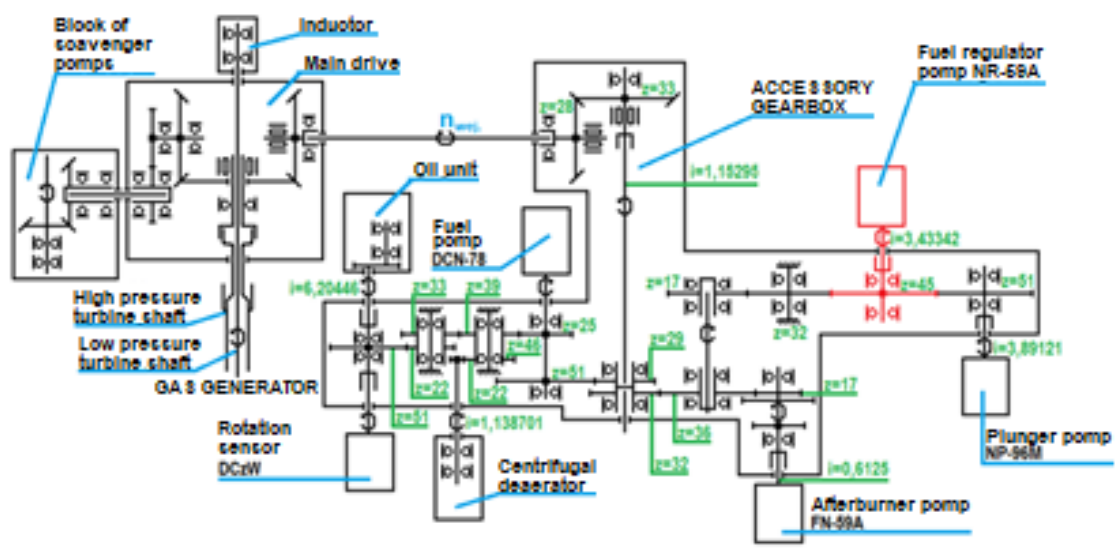

Fig. 3. Kinematic diagram of the main drive and AGB. Red denotes a critical kinematic pair $(\mathrm{z}$ - number of teeth of a given gear, $\mathrm{i}$ - location relative to the input rotational speed), source: instruction of operating manual of the RD-33 engine

The problems with the gear in NR-59A pump drive aggravated following Poland's accession to NATO, since the access to the original parts in the RD-33 engine was then limited. The substitute manufactured in Poland is more susceptible to damage in comparison to the original gear. Frequently, new gears are not accepted by preliminary inspections of the WZL No. 4, among others due to the incorrect performance of splines.

The lack of new gears at this stage reveals a new problem in the Air Force of the Republic of Poland - reducing the effectiveness of quality control in production plants, which affects:

a) complaints submitted to the manufacturer by the overhaul facility and disturbances of overhaul plan of the RD-33 engines,

b) failures of the RD-33 engines and atypical diagnostic symptoms observed in MiG-29, which influence the combat readiness of units operating MiG-29 and may result in aircraft accident due to technical reasons. 


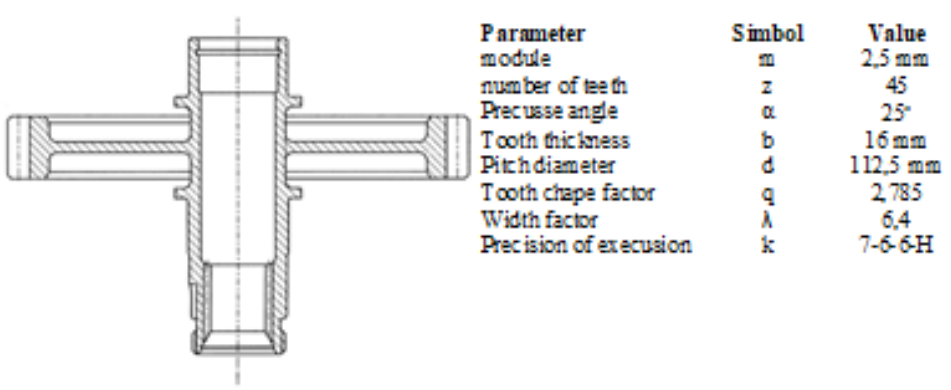

Fig. 4. 380600019 gear in the drive of NR-59A fuel regulator pump, source: WZL documentation

\section{Theoretical basis}

The overhaul documentation of the RD-33 engine lacks the information required for the verification of the strength of critical gear in accessory gearbox (AGB). To this end, it was necessary to determine:

- power balance of the AGB,

- torque transmitted by the critical kinematic pair,

- strength parameters of the critical gear.

\subsection{Power balance}

The power balance of the AGB was determined by summing up the power drawn by particular units directly connected with AGB. The balance omitted rotation sensor DCzW-2500A and centrifugal deaerator 088761500 - units, which do not draw power.

The theoretical value of power drawn by pumps is determined from [13]:

$$
P_{T}=Q_{g t} \Delta p_{g}
$$

where: $Q_{g t}$ - theoretical efficiency of a pump, $\Delta p_{g}$ - difference of forcing pressures.

The real power necessary for the pump drive depends on the torque observed on the shaft driving the pump. Assuming the fixed pump efficiency driving power of the pump is calculated from [13]:

$$
P_{N}=2 \pi M_{g t} n
$$

where: $M_{g t}$-torque on the pump shaft, $n$-pump rotational speed. 
Fuel regulator pumps NR-59A and plunger pump NP-96M are axial multipiston pumps with the deflected disc. The theoretical efficiency for the above pumps can be given as follows [13]:

$$
Q_{g t}=f_{z} D_{p} n \tan \gamma
$$

where: $f$ - cross-section of one piston, $z$ - total number of pistons, $D_{p}-$ circle diameter of piston spacing, $n$ - pump rotational speed, $\gamma$ - maximum deviation angle of the disc in the pump.

The torque value for the multi-piston pump is determined based on the following equation [13]:

$$
M_{g t}=\frac{p f z D_{p} \tan \gamma}{2 \pi}
$$

where: $p$ - pump pressure, $f$-a cross-section of one piston, $z$-number of pistons, $D_{p}$ - circle diameter of piston spacing, $\gamma$ - maximum deviation angle of the disc in the pump.

Oil unit and block of scavenger pumps belong to gear pumps. The oil flowing to the pumps fills clearance and then is provided to the discharge outlet. Efficiency value is significantly affected by the tooth profile in gears. Both analysed pumps have teeth with the evolvent profile; thus, the theoretical effectiveness of the pump is computed from [13]:

$$
Q_{g t}=\pi b n\left[r_{w 1}^{2}+\frac{r_{t 1}}{r_{t 2}} \cdot r_{w 2}^{2}-r_{t 1}\left(r_{t 1}+r_{t 2}\right)-\frac{1,108 t_{z}^{2}}{12}\left(1+\frac{r_{t 1}}{r_{t 2}}\right)\right]
$$

where: $b$ - width of gears, $n$-pump rotational speed, $r_{w l}$ - radius of an orifice of the driving gear, $r_{w 2}$ - radius of an orifice of the driven gear, $r_{t l}-$ pitch radius of the driving gear, $r_{t 2}-$ pitch radius of the driven gear, $t_{z}-$ pitch.

Torque value of gear pumps is defined as follows [13]:

$$
\begin{gathered}
M_{g t}=\frac{p \pi b m^{2}}{2 \pi \eta}\left[\left(\frac{z_{1}}{2}+x+1\right)^{2}-\frac{z_{1}}{z_{2}}\left(\frac{z_{1}}{2}+x+1\right)^{2}+\right. \\
\left.+\frac{z_{1}}{4}\left(z_{2}-z_{1}\right) \frac{\cos ^{2} \alpha_{o}}{\cos ^{2} \alpha_{t}}-\left(1-\frac{z_{1}}{z_{2}}\right) \frac{\pi^{2} \cos ^{2} \alpha_{o}}{12}\right]
\end{gathered}
$$


where: $p$ - pressure, $\eta$ - pump efficiency, $b$ - width of gears, $m$ - module, $z_{l}-$ number of gears on the driving gear, $z_{2}$ - number of gears on the driven gear, $x$ - addendum modification coefficient, $\alpha_{o}$ - nominal pressure angle, $\alpha_{t}-$ transverse pressure angle.

In gear transmission, there are energy losses resulting from gears mating with each other (sliding and friction). Taking into account the impact of friction, the efficiency of meshing in gear transmissions is written as [9]:

$$
\eta=1-\frac{8 \mu(1+i)}{z \pi \sin ^{2} 2 \alpha}
$$

where: $\mu$-coefficient of friction, $i$ - gear ratio, $z$ - number of teeth, $\alpha$-pressure angle.

\subsection{Strength criteria}

A critical part of the gear is tooth [9]. Theoretically speaking, the most significant impact on the durability of gears is attributed to bending of gears and contact stress (source of pitting) $[9,11]$.

As a part of bending strength calculations, a minimum module is determined, by which a gear withstands the following loads [11]:

$$
m=\sqrt[3]{\frac{2 M_{s} K_{p} K_{v} q}{K_{\varepsilon} \lambda z K_{g j}}}
$$

where: $M s$ - torque moment, $K_{p}$ - overload factor, $K_{v}$ - internal dynamic factor, $q$ - tooth shape factor, $K_{\varepsilon}$ - coefficient depending on the tooth contact ratio, $\lambda$ - tooth width factor, $z$ - number of teeth, $K_{g j}$ - allowable unitary bending stress.

Coefficient $K_{\varepsilon}$ depending on the tooth contact ratio equals 1 for gears with straight teeth [1]. Internal dynamic factor $K_{v}$ depends on the dynamic speed $v$, calculated from the following formula [11]:

$$
v=\frac{\pi m z n}{60000}
$$

where: $m$ - module, $z$ - number of teeth, $n$ - rotational speed. 
Overload factor $K_{p}$ is determined based on the character of work in the driving gear, engine type and the number of continuous work hours per day. These data are determined according to Henriot as comprehensively as possible (tab. 1).

Bending moment $M_{s}$ depends on the rotational speed, with which the gear moves, and power of transmission, for which the gear works [11]:

$$
M_{S}=9550 \cdot \frac{P}{n}
$$

where: $P$ - transmission power, $n$ - rotational speed.

To eliminate pitting on the working surface in teeth, strength on Hertz' contact stresses [11] are tested. The greatest stresses occur shallowly below the surface (its location depth depends on the geometry of mating elements), which facilitates the formation of spallings (craters). Not to mention that pitting is also considerably influenced by dynamic loads and gullet clearance.

Table 1

Values of overload factor according to Henriot [9]

\begin{tabular}{|l|c|c|c|}
\hline \multirow{2}{*}{ Drive } & \multirow{2}{*}{$\begin{array}{c}\text { Character of receiver } \\
\text { overload }\end{array}$} & \multicolumn{2}{c|}{ Number of work hours per day } \\
\cline { 3 - 4 } & from 12 & $\mathbf{2 4}$ \\
\hline \multirow{2}{*}{$\begin{array}{l}\text { Electric engines } \\
\text { Turbines }\end{array}$} & I & 1 & 1,05 \\
& III & 1,25 & 1,45 \\
Multi-cylinder combustion & I & 1,25 & 1,75 \\
engines & II & 1,5 & 1,45 \\
& III & 1,75 & 1,75 \\
Single-cylinder combustion & I & 1,5 & 2,25 \\
engines & II & 1,75 & 1,75 \\
& III & 2,25 & 2,25 \\
\hline
\end{tabular}

$$
P_{M A X}=C \sqrt{\frac{F K_{p} K_{v}}{K_{\varepsilon} d b} \cdot\left(1+\frac{1}{i}\right)} \leq K_{O}
$$

where: $C$-Hertz constant, $F$ - circumferential force, $K_{p}$ - overload factor, $K_{v}-$ internal dynamic factor, $q$ - tooth shape factor, $K_{\varepsilon}$ - coefficient depending on the tooth contact ratio, $d$-pitch diameter of gear, $b$ - gear width, $i$ - gear ratio, $K_{o}-$ allowable contact stresses. 
Circumferential force $\mathrm{F}$, depending on the bending moment, with which the gear is loaded and pitch diameter of this gear [11]:

$$
F=\frac{2 M_{S}}{d}
$$

where: $M_{s}-$ bending moment, $d-$ pitch diameter.

Hertz constant for steel is $C=478,2 \sqrt{\mathrm{MPa}}$ [11], but gear ratio $i$ is determined as a relation of rotational speed in gear relative to the main drive [9]. The permissible contact stresses $\mathrm{K}_{\mathrm{o}}$ can be given as [11]:

$$
K_{o}=\frac{5 H B}{w}
$$

where: $H B$ - hardness in Brinell scale, $w$-coefficient dependent on rotational speed and required work-time.

The connection of the studied gear with the torsional shaft, which is joined with the fuel regulator pump NR-59A has a form of splines (fig. 5). The durability of splines is tested against contact stresses [19]:

$$
p=\frac{8 M_{S}}{\left(D^{2}-d^{2}\right) I z \varphi} \leq K_{d}
$$

where: $F$ - force acting on splines, $M_{s}$ - bending moment, $D$ - external diameter of splines, $d$-internal diameter of splines, $I$ - length of splines, $z$ - number of teeth of splines, $\varphi$ - inaccuracy execution factor of splines, $K_{d}-$ allowable contact stresses.
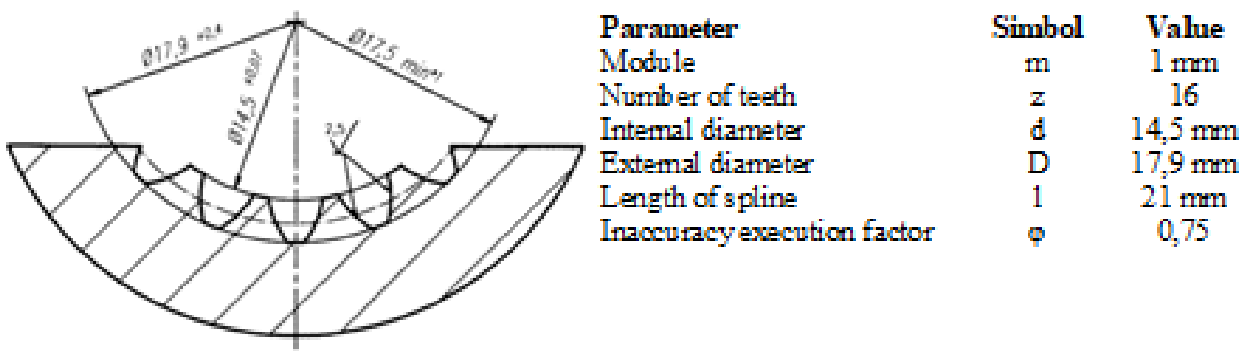

Fig. 5. Splines on gear 380600019 and its parameters [11] 


\section{Test results}

\subsection{Power balance}

For fuel regulator pump NR-59A and plunger pump NP-96M, it was assumed that pumping pressure, controlled during static ground tests, can vary from 0 to the maximum value.

Gears located in the oil unit have standard corrected teeth with evolvent profile. Ratio between gears is 1 . In such a case, values of pressure angles (nominal and rolling) are the same $\left(\alpha_{0}=30^{\circ}\right.$ for both pumps). The number of teeth and radiuses of gears are also the same. The oil unit and block of scavenger pumps work with limited efficiency, taking into account the safety factor. Its value is identical for both pumps $(\mathrm{H}=78,7 \%)$, likewise for modules ( $m=4 \mathrm{~mm}, r_{w}=19 \mathrm{~mm}, r_{t}=14 \mathrm{~mm}$ ).

The afterburner pump FN-59A and fuel pump DCN-78 have pre-determined theoretical efficiency $Q_{t}$, which are investigated in production and overhaul facility. Once the formula for the theoretical power of the pump was used and the maximum pressure values applied during static ground tests were taken into consideration, the theoretical power of both pumps was determined (tab. 2). The adopted parameters and results of calculations for all of the above mentioned pumps were shown in tab. 2 .

Table 2

Parameters of pumps connected with AGB, source: manufacturer's data and documentation of WZL

\begin{tabular}{|l|l|l|l|l|l|l||}
\hline $\begin{array}{l}\text { Parameter } \\
\text { pump }\end{array}$ & NR-59A & NP-96M & Oil unit & $\begin{array}{l}\text { Block of scavenger } \\
\text { pumps }\end{array}$ & FN-59A & DCN-78 \\
\hline$N[\mathrm{obr} / \mathrm{min}]$ & 4600 & 4100 & 3000 & 6000 & 25600 & 4000 \\
\hline$P[\mathrm{MPa}]$ & 9,5 & 21,9 & 0,4 & 0,1 & 0,98 & 2,4 \\
\hline$Q_{g t}\left[\mathrm{dm}^{3} / \mathrm{min}\right]$ & 153,69 & 20 & 45,36 & 158,77 & 425 & 118 \\
\hline$M_{g t}[\mathrm{Nm}]$ & 50,52 & 17 & 0,96 & 0,42 & 2,59 & 11,27 \\
\hline$\underline{P_{T}[\mathrm{~kW}]}$ & $\underline{24,334}$ & $\underline{7,3}$ & $\underline{0,302}$ & $\underline{0,264,625}$ & $\underline{6,94}$ & $\underline{4,72}$ \\
\hline$\underline{P_{N}[\mathrm{~kW}]}$ & $\underline{24,334}$ & $\underline{7,3}$ & $\underline{0,302}$ & $\underline{0,264,507}$ & $\underline{6,94}$ & $\underline{4,72}$ \\
\hline
\end{tabular}

The main drive is a toothed gear with three conical gears mating with each other and additionally, two cylindrical gears connected with the block of scavenger pumps. It is applied to provide driving power from the engine to the AGB with the value of approx. $0,2 \%$ of the power generated in the engine. The power in gas generator can be estimated utilizing simulation programmes, knowing the measured engine parameters, engine type and aircraft operational constraints. The examples of input data for the numerical analysis were illustrated in tab.3. 
Table 3

Selected parameters of MIG-29 aircraft, source: [27] and operating manual of the RD-33 engine

\begin{tabular}{||l|l|}
\hline \multicolumn{1}{|c|}{ Parameter } & \multicolumn{1}{c|}{ Value } \\
\hline lifting surface & $35,2 \mathrm{~m}^{2}$ \\
\hline maximum total mass & $18000 \mathrm{~kg}$ \\
\hline engine thrust & $50,4 \mathrm{kN}$ \\
\hline maximum revolutions in low-pressure compressor & $11000 \mathrm{obr} / \mathrm{min}$ \\
\hline maximum revolutions in high-pressure compressor & $15539 \mathrm{obr} / \mathrm{min}$ \\
\hline pressure ratio (compression ratio) in low-pressure compressor & 3,2 \\
\hline pressure ratio in high-pressure compressor & 18 \\
\hline exhaust temperature at the outlet & $1680 \mathrm{~K}$ \\
\hline
\end{tabular}

Calculations were done using the "GasTurb13" programme and universal characteristics (maps) of compressor and turbine [3]. As a result of calculations made for double-shaft turbojet engine, power in gas generator amounting to $14885 \mathrm{~kW}$, was obtained. Providing that approx. $0,2 \%$ of the power generated in the engine is transmitted to the main drive; its power is $29,77 \mathrm{~kW}$. Adding up the acquired power values for the above units, the total power of the AGB equalling $72,8 \mathrm{~kW}$ was obtained. The computed power value was adopted for further calculations concerning the critical gear.

Coefficient of friction $\mu$ depends on the material of mating elements and the type of load (static or dynamic). Bearing in mind that a toothed gear is under fatigue loads, the coefficient of friction $\mu$ is within the range from 0,09 to 0,03 [2]. The efficiency in AGB falls within the range of $96,1 \% \div 98,7 \%$.

\subsection{Strength criteria of gear teeth in AGB}

The adopted parameters and strength calculations for gear were presented in tab. 4 .

Table 4

Strength parameters for a gear, source: $[17,18]$ and documentation of WZL

\begin{tabular}{|l|c|c|c|c|c|}
\hline \multicolumn{1}{|c|}{ Parameter } & $\mathbf{v}$ & $\mathbf{M}_{\mathbf{s}}$ & $\mathbf{M}$ & $\mathbf{F}$ & PMAX \\
\hline Value & $27,1 \mathrm{~m} / \mathrm{s}$ & $151,14 \mathrm{Nm}$ & $\geq 2,076 \mathrm{~mm}$ & $2686,9 \mathrm{~N}$ & $1090,91 \mathrm{MPa}$ \\
\hline
\end{tabular}


Converting the hardness from Rockwell $\mathrm{C}$ scale to Brinell scale, a value range from $287 \mathrm{HB}$ to $372 \mathrm{HB}$ is obtained [16]. Coefficient $w$, occurring in the denominator of formula (16), is determined using the method of linear interpolation from the table depending on the value of rotational speed and the required worktime [11]. In the production of a gear, carbonization process is applied, which is aimed at hardening the teeth on the surface using the diffuse saturation (layer thickness $0,2 \mathrm{~mm}$ ), which results in the hardness of teeth surface increasing to 60-64 HRC [5]. The range of allowable contact stresses (16) is then changed [11, 16]. Table 5 consists of the calculations of extreme allowable contact stresses.

Table 5

Strength parameters for a gear, source: $[5,11,16]$ and documentation of WZL

\begin{tabular}{||l|c|c|c|c||}
\hline \hline Parameter & $\mathbf{w}$ & $\mathbf{T}$ & KoMIN $_{\text {o }}$ & KoMAx $_{\text {ou }}$ \\
\hline Value & 2,964 & $1600 \mathrm{~h}$ & $1096,47 \mathrm{MPa}$ & $1214,57 \mathrm{MPa}$ \\
\hline
\end{tabular}

\subsection{Strength criteria of gear splines in the AGB}

The allowable contact stresses for splines $K_{d}$, made from steel 12H2NWFA$\mathrm{WD}$, amount to $441 \mathrm{MPa}$ [5]. Substituting in formula (14) design data, we obtain a value of theoretical stresses on splines: $F=18659,15 \mathrm{~N}$ i $p=43,56 \mathrm{MPa}$. Theoretically, the splines shall not be damaged during the usage of AGB. The obtained results of strength calculations do not reflect the operational problems of splines.

\section{Summary and conclusions}

Based on the conducted strength calculations conducted for the original gear material and parameters of thermal and mechanical treatment, it was found that the original gear 380600019 of the AGB satisfies the bending strength of teeth and contact stresses of splines. The condition of teeth resistance to contact stresses is met once they are carburized on the external surface with the layer of $0,2 \mathrm{~mm}$ thickness resulting in saturating the steel surface in carbon.

The obtained positive results of strength calculations of original gear 380600019 of the AGB do not reflect fatigue problems observed in the Polish substitute of this gear. The substitute is damaged several times which may be due to the dissimilarity of the mechanical parameters of the applied material (chemical composition, microstructure, purity grade); quality of thermal and chemical 
treatment and impact of internal stresses. A credible explanation of the reasons requires further study, which should be aimed at estimating the strength of gear and torsional shaft based on the available technical conditions and estimation methods of strength [21] as well as the selected methods of non-destructive testing [8].

The highest number of operational problems regarding the substitute of gear is observed in splines, where a strength criteria for an original gear is met with a very big margin. Frequent problems are fretting and overheating, which is influenced by a) parameters of the galvanic layer (oxidizing, oxido-phosphatizing) reducing friction in kinematic pair and increasing its resistance to corrosion,

b) lubrication and cooling parameters of this particular kinematic pair.

These parameters were omitted in the first stage of studying the operational problem and in this article.

Gear wheel and torsional shaft are constructed from a ferromagnetic material, which enables the usage of modern magnetic and electromagnetic methods in nondestructive quality control of the material and technical condition of critical elements [10].

\section{References}

1. Bagiński A., Kułaszka A., Szczepankowski A., Szymczak A.: The diagnosing of turbines of turbomachinery with a visual non-destructive method. Journal of KONBiN 1(17) 2011.

2. fizyka.edu.pl - współczynniki tarcia.

3. gasturb.de - program „GasTurb13”.

4. geology.com/minerals/graphite.shtml - graphite.

5. GOST 11268-76, rosyjska norma państwowa.

6. Karczewski M., Walentynowicz J.: Wpływ mieszanin paliwa F-34 z biokomponentami na osiągi silnika z zasobnikowym układem wtryskowym. Biuletyn WAT vol. LIX, nr $1,2010$.

7. Mike J., Wesołowski J.: Samolot MIG-29. Opis techniczny. Malbork 2005.

8. ndt.net/search/docs.php3.

9. Ochęduszko K.: Koła zębate. Wyd. Naukowo-Techniczne, Warszawa 1985.

10. Roskosz M., Witoś M., Zieja M.: Examination of Technical Gear with the Help of Magnetic Passive Observer Status. Poster in the $11^{\text {th }}$ European Conference on NonDestructive Testing, 6th-10th October 2014, Prague, Czech Republic.

11. Rutkowski A.: Części maszyn. Wyd. WSIP, Warszawa 1992.

12. Sałaciński M., Stefaniuk M., Synaszko P., Lisiecki J.: Use of a composite repair parches to repair the upper air intake flap for the MiG-29 aircraft engine. Aviation Advances \& Maintenance, Vol. 40, Iss. 2, DOI 10.1515/afit-2017-0010. 
13. Stryczek S.: Napęd hydrostatyczny. Tom 1, Wyd. Naukowo-Techniczne, Warszawa 1990.

14. Trelka M., Bartoszewicz J., Urbaniak J.: Selected problems of RD-33 engine Reliability in operation. Combustion Engines, 2016.

15. Witoś, M., Zieja, M., Szczepankowski, A., Szymczak, J.: Structural health monitoring of aero-engines in non-stationary operations. Applied Condition Monitoring 9, Gliwice 2016.

16. www.cogne.com - Hardness tables, "the conversion between $\mathrm{HB}-\mathrm{HV}-\mathrm{HRC}-\mathrm{HRB}$ Hardness".

17. www.gov.pl/web/obrona-narodowa.

18. www.klimov.ru.

19. www.pkm.edu.pl - obliczanie połączeń wielowypustowych.

20. www.samoloty.pl - encyklopedia lotnicza, samolot MIG-29.

21. Zieja M., Ważny M., Stępień S.: Outline of a method for estimating the durability of components or device assemblies while maintaining the required reliability level. Eksploatacja i Niezawodność - Maintenance and Reliability, 20(2), 2018. 


\section{ANALIZA WYTRZYMALOŚCIOWA KRYTYCZNEJ PARY KINEMATYCZNEJ SILNIKA RD-33}

\section{Wprowadzenie}

Pod koniec lat sześćdziesiątych XX w. na terenie ZSRR rozpoczęto prace na trzecią generacją samolotów myśliwskich. Nowo projektowany samolot myśliwski MiG-29 miał być przeciwwagą dla amerykańskiego F-15. W 1971 r. opracowano pierwsze oficjalne wymagania dla nowego samolotu, w konfiguracji zbliżonej do samolotu MiG-25. Przez kolejne cztery lata założenia konstrukcyjne ulegały modyfikacjom. Już 6 października 1977 r. wykonano pierwszy oblot prototypu [20]. Próby państwowe MiGa-29 zakończono w 1983 r. i rozpoczęto produkcję pierwszej partii seryjnej. Myśliwiec wyposażony w dwa dwuprzepływowe silniki odrzutowe RD-33 został włączony do uzbrojenia armii radzieckiej w 1987 r. [20]. Rok później odbyła się jego pierwsza demonstracja za granicą, na pokazie lotniczym w Farnborough (Wielka Brytania) [18]. W 1989 r. samoloty MiG-29 zaczęto wdrażać w polskim lotnictwie wojskowym (obecnie lotnictwie Sił Zbrojnych RP, LSZ RP), gdzie po dziś dzień są eksploatowane przez dwie jednostki wojskowe na terenie Polski i w misjach zagranicznych [17].

Wraz z samolotami MiG-29 pojawiły się różne problemy eksploatacyjne z ich silnikami, mające wpływ na bezpieczeństwo lotów. Najbardziej newralgicznym miejscem w silniku RD-33, ze względu na jego budowę (rys. 1) i zasadę działania [14], są łopatki sprężarki niskiego i wysokiego ciśnienia. Problem wynika z zasysania do silnika ciał obcych, które powodują uszkodzenia mechaniczne łopatek, zmianę rozkładu sił masowych, niewyważenia wirnika i wzrost drgań silnika. W efekcie istnieje ryzyko urwania zmęczeniowego łopatki, a w sporadycznych przypadkach całkowitego zablokowania pędni wirnika [15]. Innym źródłem ciał obcych wpadających do silnika były odpadające nity elementów górnego wlotu powietrza [12]. 


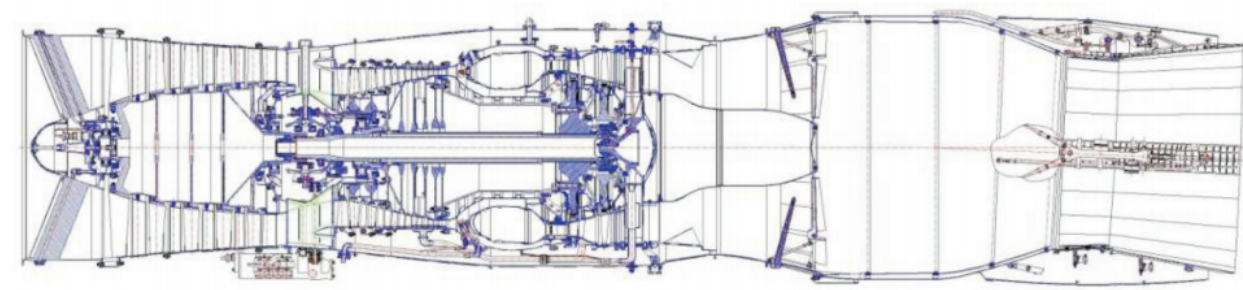

Rys. 1. Przekrój silnika RD-33 [5]

$\mathrm{Na} ł$ łopatkach turbiny dominują przegrzania krawędzi natarcia i korozja wysokotemperaturowa, której źródłem są m.in. [1]:

a) zastosowane rozwiązanie konstrukcyjne włączania dopalacza,

b) stosowane powłoki ochronne łopatek,

c) zmiana typu paliwa z PSM-2 na F-34 (używanego w NATO) [6],

d) zmiana rozkładu pola temperatur spalin przed turbiną,

e) sporadyczne błędy regulacji układu paliowego silnika.

Przykładowe uszkodzenia łopatek turbiny, wykrywane podczas okresowych badań nieniszczących, zobrazowano na rys. 2 [1].
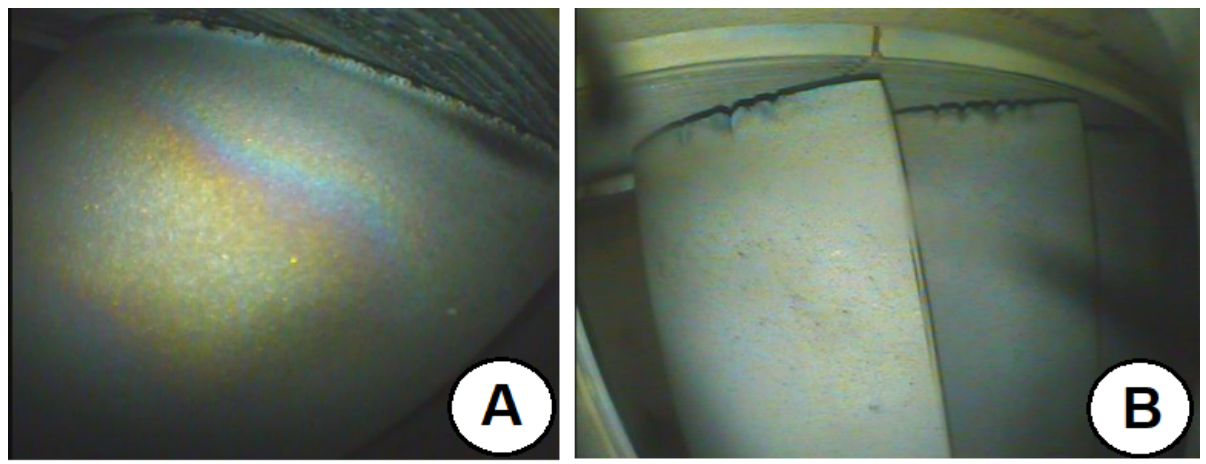

Rys. 2. Przykładowe uszkodzenia na łopatkach TWC [1] (A - przebarwienia, B - pęknięcia)

Poważnym problemem eksploatacyjnym silników RD-33 są również wypracowania grafitowego uszczelnienia tylnej podpory. Uszczelnienia są wykonane z grafitu o kruchości między 1 a 2 w skali Mohsa (ok. 40 HV) [4]. Pod wpływem zwiększonego poziomu drgań silnika, na powierzchni uszczelnienia pojawiają się rysy oraz mikropęknięcia, które pogarszają jakość uszczelnienia i są przyczyną podciekania. Negatywny wpływ na łożyska podpór pędni silnika mają również dynamiczne obciążenia i wibracje pojawiające się podczas pracy łopatek TWC i TNC [15]. 
Od kilku lat na silnikach RD-33 eksploatowanych w LSZ RP narasta również problem przyśpieszonej degradacji zmęczeniowej połączenia kinematycznego skrzynki napędów agregatów (SNA) z pompą regulatora paliwa NR-59A. Na tym właśnie problemie skupiono uwagę $\mathrm{w}$ niniejszym artykule, przedstawiając wybrane wyniki analizy wytrzymałościowej.

\section{Obiekt badań}

Najbardziej newralgicznym miejscem w SNA (rys. 3) jest koło zębate napędu pompy regulatora paliwa NR-59A, którego geometrię i parametry konstrukcyjne zobrazowano na rys. 4. Oryginalne koło zębate zostało wykonane ze stali 12H2NWFA-WD, dla której dopuszczalne naprężenia gnące $\mathrm{K}_{\mathrm{gj}}$ mają wartość 882 $\mathrm{MPa}$, natomiast twardość zawiera się w przedziale od $30 \mathrm{HRC}$ do $40 \mathrm{HRC}$ [5]. Głównymi przyczynami brakowania tego koła zębatego w remoncie silnika RD-33 są (na podstawie dokumentacji WZL):

- nadmierne ślady wypracowań (starć),

- korozja lub zużycie ścierno-korozyjne (ang. fretting) na wielowypuście współpracującym z wałkiem,

- wżery (ang. pitting),

- mikropęknięcia na powierzchniach roboczych zębów

- ślady barw nalotowych powstających w wyniku przegrzania materiału.

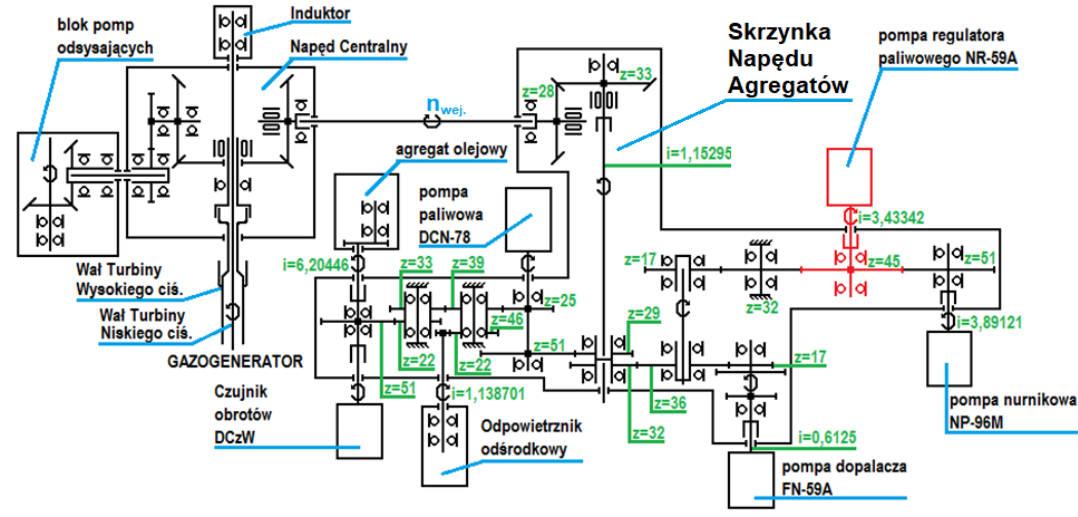

Rys. 3. Schemat kinematyczny napędu centralnego i SNA. Kolorem czerwonym zaznaczono krytyczną parę kinematyczną ( $\mathrm{z}$ - liczba zębów danego koła zębatego, i - przełożenie względem wejściowej prędkości obrotowej), źródło: instrukcja eksploatacji silnika RD-33 
Problemy z kołem zębatym napędu pompy NR-59A nasiliły się po wstąpieniu Polski do NATO, kiedy ograniczony został dostęp do oryginalnych części silnika RD-33. Zamiennik produkowany w Polsce jest bardziej podatny na uszkodzenia $\mathrm{w}$ porównaniu $\mathrm{z}$ oryginalnym kołem zębatym. Często nowe koła zębate nie przechodzą nawet kontroli wejściowej w Wojskowych Zakładach Lotniczych $\mathrm{nr} 4$, m.in. z powodu źle wykonanego wielowypustu.

Poziom brakowania nowych kół na tym etapie ujawnia kolejny problem w otoczeniu LSZ RP - obniżenie efektywności kontroli jakości w zakładach produkcyjnych, który wpływa na:

a) poziom reklamacji zgłaszanych producentowi przez zakład remontowy i zaburzenia planu remontowego silników RD-33,

b) poziom usterek silnika RD-33 i nietypowych symptomów diagnostycznych obserwowanych u użytkownika samolotów MiG-29, które wpływają na gotowość bojową jednostek eksploatujących samoloty MiG-29 i mogą zakończyć się wypadkiem lotniczym z przyczyn technicznych.

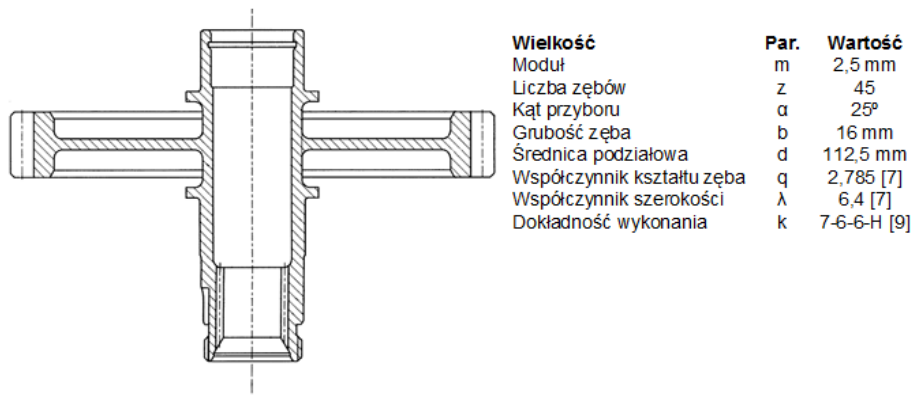

Rys. 4. Koło zębate 380600019 napędu pompy regulatora paliwa NR-59A, źródło: dokumentacja WZL

\section{Podstawy teoretyczne}

W dokumentacji remontowej silnika RD-33 brak jest bezpośredniej informacji wymaganej do weryfikacji wytrzymałości krytycznego koła zębatego w SNA. W tym celu niezbędne było wyznaczenie:

- bilansu mocy SNA,

- momentu obrotowego przenoszonego przez krytyczną parę kinematyczną,

- parametrów wytrzymałościowych krytycznego koła zębatego. 


\subsection{Bilans mocy}

Bilans mocy SNA wyznaczono poprzez zsumowanie mocy pobieranej przez poszczególne agregaty podłączone bezpośrednio z SNA. W bilansie pominięto czujnik obrotów DCzW-2500A i odpowietrznik odśrodkowy 088761500 - urządzenia, które nie pobierają mocy.

Teoretyczną wartość mocy pobieranej przez pompy wyznacza się z zależności [13]:

$$
P_{T}=Q_{g t} \Delta p_{g}
$$

gdzie: $Q_{g t}$ - wydajność teoretyczna pompy, $\Delta p_{g}$ - różnica ciśnień tłoczenia.

Rzeczywista moc niezbędna do napędu pompy zależy od momentu obrotowego na wale napędzającym pompę. Przyjmując stałą wydajność pompy, moc napędową pompy oblicza się z zależności [13]:

$$
P_{N}=2 \pi M_{g t} n
$$

gdzie: $M_{g t}$ - moment obrotowy na wałku pompy, $n$ - prędkość obrotowa pompy.

Pompy regulatora paliwa NR-59A i pompa nurnikowa NP-96M są pompami wielotłoczkowymi osiowymi $\mathrm{z}$ wychylną tarczą. Wydajność teoretyczną dla powyższych pomp można wyznaczyć z relacji [13]:

$$
Q_{g t}=f z D_{p} n \tan \gamma
$$

gdzie: $f$ - przekrój poprzeczny jednego tłoczka, $z$ - łączna liczba tłoczków, $D_{p}-$ średnica okręgu rozstawu tłoczków, $n$ - prędkość obrotowa z jaką pracuje pompa, $\gamma$ - maksymalny kąt odchylenia tarczy w pompie.

Wartość momentu obrotowego dla pomp wielotłoczkowych wyznacza się na podstawie wzoru [13]:

$$
M_{g t}=\frac{p f z D_{p} \tan \gamma}{2 \pi}
$$

gdzie: $p$ - ciśnienie pompy, $f$ - przekrój poprzeczny jednego tłoczka, $z$ - liczba tłoczków, $D_{p}$ - średnica okręgu rozstawu tłoczków, $\gamma$ - maksymalny kąt odchylenia tarczy w pompie. 
Agregat olejowy oraz blok pomp odsysających to pompy zębate. Dopływający do pomp olej wypełnia przestrzenie międzyzębne, a następnie jest unoszony do wylotu tłocznego. Na wartość wydajności znaczący wpływ ma zarys zębów w kołach. W obu analizowanych pompach są zęby z zarysem ewolwentowym, stąd wydajność teoretyczną pompy można wyznaczyć z zależności [13]:

$$
Q_{g t}=\pi b n\left[r_{w 1}^{2}+\frac{r_{t 1}}{r_{t 2}} \cdot r_{w 2}^{2}-r_{t 1}\left(r_{t 1}+r_{t 2}\right)-\frac{1,108 t_{z}^{2}}{12}\left(1+\frac{r_{t 1}}{r_{t 2}}\right)\right]
$$

gdzie: $b$ - szerokość kół zębatych, $n$-prędkość obrotowa pompy, $r_{w l}$-promień otworu, w którym umieszczone jest koło czynne, $r_{w 2}$ - promień otworu, w którym umieszczone jest koło bierne, $r_{t 1}$ - promień podziałowy koła czynnego, $r_{t 2}$ - promień podziałowy koła biernego, $t_{z}$ - podziałka.

Wartość momentu obrotowego pomp zębatych określa zależność [13]:

$$
\begin{aligned}
M_{g t}= & \frac{p \pi b m^{2}}{2 \pi \eta}\left[\left(\frac{z_{1}}{2}+x+1\right)^{2}-\frac{z_{1}}{z_{2}}\left(\frac{z_{1}}{2}+x+1\right)^{2}+\right. \\
& \left.+\frac{z_{1}}{4}\left(z_{2}-z_{1}\right) \frac{\cos ^{2} \alpha_{o}}{\cos ^{2} \alpha_{t}}-\left(1-\frac{z_{1}}{z_{2}}\right) \frac{\pi^{2} \cos ^{2} \alpha_{o}}{12}\right]
\end{aligned}
$$

gdzie: $p$ - ciśnienie, $\eta$ - sprawność pompy, $b$ - szerokość kół zębatych, $m$ - moduł,

$z_{1}$ - liczba zębów na kole czynnym, $z_{2}$ - liczba zębów na kole biernym, $x-$ współczynnik przesunięcia profilu, $\alpha_{o}$ - nominalny kąt przyporu, $\alpha_{t}$ - toczny kąt przyporu.

W przekładni zębatej występują straty energii wynikające ze współpracy kół zębatych ze sobą (poślizg i tarcie). Uwzględniając wpływ tarcia, można wyznaczyć sprawność zazębienia przekładni zębatych z zależności [9]:

$$
\eta=1-\frac{8 \mu(1+i)}{z \pi \sin ^{2} 2 \alpha}
$$

gdzie: $\mu$-współczynnik tarcia, $i$ - przełożenie, $z$ - liczba zębów, $\alpha$ - kąt przyporu.

\subsection{Kryteria wytrzymałościowe}

Krytycznym fragmentem koła zębatego są zęby [9]. Teoretycznie największy wpływ na wytrzymałość kół zębatych mają zginanie zębów i naciski powierzchniowe (źródło pittingu) $[9,11]$. 
W ramach obliczeń wytrzymałościowych na zginanie wyznacza się minimalny moduł, przy którym koło wytrzyma obciążenia [11]:

$$
m=\sqrt[3]{\frac{2 M_{s} K_{p} K_{v} q}{K_{\varepsilon} \lambda z K_{g j}}}
$$

gdzie: $M s$ - moment skręcający, $K_{p}$ - współczynnik przeciążenia, $K_{v}-$ współczynnik nadwyżek dynamicznych, $q$ - współczynnik kształtu zęba, $K_{\varepsilon}$ - współczynnik zależny od liczby przyboru, $\lambda$ - współczynnik szerokości zęba, $z$ - liczba zębów, $K_{g j}$ - dopuszczalne jednostkowe naprężenia gnące.

Współczynnik $K_{\varepsilon}$ zależny od liczby przyboru ma wartość równą 1 dla kół zębatych o zębach prostych [1]. Współczynnik nadwyżek dynamicznych $K_{v}$ zależy od prędkości dynamicznej $v$, obliczonej z poniższego wzoru wartości [11]:

$$
v=\frac{\pi m z n}{60000}
$$

gdzie: $m$ - modul, $z$ - liczba zębów, $n$ - prędkość obrotowa.

Współczynnik przeciążenia $K_{p}$ określa się na podstawie charakteru pracy mechanizmu napędowego, rodzaju silnika oraz od liczby godzin pracy ciągłej silnika na dobę. Dane te w sposób najbardziej wyczerpujący są określone wg Henriota (tab. 1).

Moment skręcający $M_{s}$ zależy od prędkości obrotowej, z jaką porusza się koło zębate, oraz mocy przekładni, dla której pracuje to koło [11]:

$$
M_{s}=9550 \cdot \frac{P}{n}
$$

gdzie: $P$ - moc przekładni, $n$ - prędkość obrotowa.

W celu wyeliminowania pittingu na powierzchni roboczej zębów sprawdzany jest warunek wytrzymałościowy (11) na naciski powierzchniowe Hertza [11]. Największe naprężenia występują płytko pod powierzchnią (głębokość ich położenia jest zależna od geometrii współpracujących elementów), co sprzyja powstawaniu odprysków materiału (kraterów). Na zjawisko pittingu istotny wpływ ma poziom obciążeń dynamicznych i luzy międzyzębne. 


\section{Tabela 1}

Wartości wspólczynnika przeciążenia wg Henriota [9]

\begin{tabular}{||l|c|c|c|}
\hline \multirow{2}{*}{ Napęd } & \multirow{2}{*}{$\begin{array}{c}\text { Charakter obciążenia } \\
\text { odbiornika }\end{array}$} & \multicolumn{2}{|c|}{ Liczba godzin pracy na dobę } \\
\cline { 3 - 4 } & I & 1 & $\mathbf{2 4}$ \\
\hline \multirow{2}{*}{ Silniki elektryczne } & II & 1,25 & 1,05 \\
Turbiny & III & 1,5 & 1,45 \\
& I & 1,25 & 1,75 \\
\hline \multirow{2}{*}{ Silniki spalinowe } & II & 1,5 & 1,45 \\
wielocylindrowe & III & 1,75 & 1,75 \\
& I & 1,5 & 2,25 \\
\hline \multirow{2}{*}{ Silniki spalinowe } & II & 1,75 & 1,75 \\
jednocylindrowe & III & 2,25 & 2,25 \\
& \multicolumn{2}{|l}{} \\
\hline
\end{tabular}

$$
P_{M A X}=C \sqrt{\frac{F K_{p} K_{v}}{K_{\varepsilon} d b} \cdot\left(1+\frac{1}{i}\right)} \leq K_{o}
$$

gdzie: $C$ - stała Hertza, $F$ - siła obwodowa, $K_{p}$ - współczynnik przeciążenia, $K_{v}$ - współczynnik nadwyżek dynamicznych, $q$ - współczynnik kształtu zęba, $K_{\varepsilon}$ - współczynnik zależny od liczby przyporu, $d$ - średnica podziałowa koła zębatego, $b$ - szerokość koła zębatego, $i$ - przełożenie, $K_{o}$ - dopuszczalne naciski powierzchniowe.

Siła obwodowa F, zależna od momentu skręcającego, z jakim obciążone jest koło zębate, oraz od średnicy podziałowej tego koła [11]:

$$
F=\frac{2 M_{S}}{d}
$$

gdzie: $M_{s}-$ moment skręcający, $d$ - średnica podziałowa.

Stała Hertza dla stali to $C=478,2 \sqrt{ } \mathrm{MPa}$ [11], natomiast przełożenie $i$ wyznacza się jako stosunek prędkości obrotowej koła względem napędu głównego [9]. Dopuszczalne naciski powierzchniowe $\mathrm{K}_{\mathrm{o}}$ można zapisać w postaci [11]:

$$
K_{o}=\frac{5 H B}{w}
$$

gdzie: $H B$ - twardość materiału w skali Brinella, w - współczynnik zależny od prędkości obrotowej i żądanego czasu pracy. 
Połączenie badanego koła zębatego z wałkiem skrętnym, który łączy się z pompą regulatora paliwa NR-59A ma charakter wielowypustu (rys. 5). Wytrzymałość wielowypustu sprawdza się na naciski powierzchniowe [19]:

$$
p=\frac{8 M_{s}}{\left(D^{2}-d^{2}\right) I z \varphi} \leq K_{d}
$$

gdzie: $F$ - siła działająca na wielowypust, $M_{s}$ - moment skręcający, $D$ - średnica zewnętrzna wielowypustu, $d$ - średnica wewnętrzna wielowypustu, $I$ - długość wielowypustu, $z$ - liczba zębów wielowypustu, $\varphi$ - współczynnik niedokładności wykonania wielowypustu, $\mathrm{K}_{\mathrm{d}}$-- dopuszczalne naciski powierzchniowe.

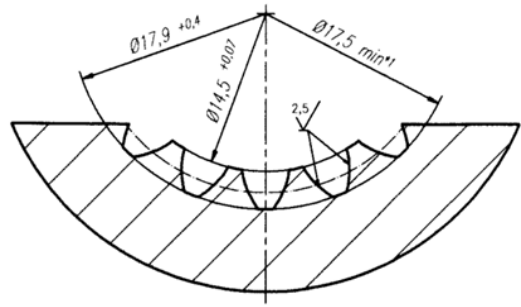

Wielkość

Moduł

Liczba zębów

Srednica wewnętrzna

Srednica zewnętrzna

Długość wielowypust

Wsp. Niedokładności wykonania

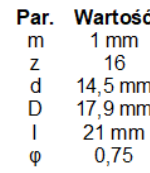

Rys. 5. Wielowypust na kole zębatym 380600019 i jego parametry [11]

\section{Wyniki badań}

\subsection{Bilans mocy}

Dla pompy regulatora paliwa NR-59A i pompy nurnikowej NP-96M przyjęto założenie, że ciśnienie tłoczenia, kontrolowane podczas prób stoiskowych, może zmieniać się od zera do wartości maksymalnej.

Koła zębate znajdujące się $\mathrm{w}$ agregacie olejowym mają zęby normalne korygowane z zarysem ewolwentowym. Przełożenie między kołami jest równe 1 . W takim układzie wartości kątów przyporu (nominalnego i tocznego) mają taką samą wartość $\left(\alpha_{o}=30^{\circ}\right.$ dla obu pomp). Liczby zębów i promienie kół też są identyczne. Agregat olejowy oraz blok pomp odsysających pracują z ograniczoną sprawnością, uwzględniającą współczynnik bezpieczeństwa. Jej wartość jest taka sama dla obu pomp $(\mathrm{H}=78,7 \%)$, dla obu pomp podobnie jak moduły $(m=4 \mathrm{~mm}$, $\left.r_{w}=19 \mathrm{~mm}, r_{t}=14 \mathrm{~mm}\right)$.

Pompa dopalacza FN-59A i pompa paliwowa DCN-78 mają odgórnie znane wydajności teoretyczne $Q_{t}$, które są sprawdzane podczas prób stoiskowych w zakładzie produkcyjnym i remontowym. Po uwzględnieniu wzoru na moc 
teoretyczną pompy i wartości maksymalne ciśnień stosowanych podczas badań stoiskowych, wyznaczono moc teoretyczną obu pomp (tab. 2). Przyjęte parametry oraz wyniki obliczeń dla wszystkich powyższych pomp zobrazowano w tab. 2.

Tabela 2

Parametry pomp połączonych z SNA, źródło: dane producenta i dokumentacja WZL

\begin{tabular}{|l|l|l|l|l|l|l|}
\hline $\begin{array}{c}\text { Parametr/ } \\
\text { pompa }\end{array}$ & NR-59A & NP-96M & $\begin{array}{c}\text { Agregat } \\
\text { olejowy }\end{array}$ & $\begin{array}{c}\text { Blok pomp } \\
\text { odsysających }\end{array}$ & FN-59A & DCN-78 \\
\hline$N[\mathrm{obr} / \mathrm{min}]$ & 4600 & 4100 & 3000 & 6000 & 25600 & 4000 \\
\hline$P[\mathrm{MPa}]$ & 9,5 & 21,9 & 0,4 & 0,1 & 0,98 & 2,4 \\
\hline$Q_{g t}\left[\mathrm{dm}^{3} / \mathrm{min}\right]$ & 153,69 & 20 & 45,36 & 158,77 & 425 & 118 \\
\hline$M_{g t}[\mathrm{Nm}]$ & 50,52 & 17 & 0,96 & 0,42 & 2,59 & 11,27 \\
\hline$\underline{P_{T}[\mathrm{~kW}]}$ & $\underline{24,334}$ & $\underline{7,3}$ & $\underline{0,302}$ & $\underline{0,264,625}$ & $\underline{6,94}$ & $\underline{4,72}$ \\
\hline$\underline{P_{N}[\mathrm{~kW}]}$ & $\underline{24,334}$ & $\underline{7,3}$ & $\underline{0,302}$ & $\underline{\underline{0,264,507}}$ & $\underline{6,94}$ & $\underline{4,72}$ \\
\hline
\end{tabular}

Napęd centralny jest przekładnią zębatą posiadającą zespół trzech stożkowych kół zębatych współpracujących ze sobą oraz dodatkowo jeden stopień walcowych kół zębatych z wyprowadzeniem na blok pomp odsysających. Poprzez niego od silnika do SNA doprowadzana jest moc napędowa o wartości ok. $0,2 \%$ mocy wytwarzanej $\mathrm{w}$ silniku. Moc gazogeneratora można oszacować za pomocą programów symulacyjnych, znając mierzone parametry silnikowe, typ silnika i ograniczenia eksploatacyjne samolotu. Przykładowe dane wejściowe do analizy numerycznej zobrazowano w tab. 3 .

\section{Tabela 3}

Wybrane parametry samolotu MIG-29, źródło: [27] oraz instrukcja eksploatacji silnika RD-33

\begin{tabular}{||l|l||}
\hline \multicolumn{1}{|c|}{ Nazwa parametru } & \multicolumn{1}{c|}{ Wielkość } \\
\hline powierzchnia nośna & $35,2 \mathrm{~m}^{2}$ \\
\hline max masa całkowita & $18000 \mathrm{~kg}$ \\
\hline ciąg silników & $50,4 \mathrm{kN}$ \\
\hline max obroty sprężarki niskiego ciśnienia & $11000 \mathrm{obr} / \mathrm{min}$ \\
\hline max obroty sprężarki wysokiego ciśnienia & $15539 \mathrm{obr} / \mathrm{min}$ \\
\hline stosunek ciśnień (spręż) w sprężarce niskiego ciśnienia & 3,2 \\
\hline spręż w sprężarce wysokiego ciśnienia & 18 \\
\hline temperatura spalin na wyjściu & $1680 \mathrm{~K}$ \\
\hline
\end{tabular}


Do obliczeń wykorzystano program „GasTurb13” i uniwersalne charakterystyki (mapy) sprężarki i turbiny [3]. W wyniku obliczeń wykonanych dla dwuwałowego silnika odrzutowego uzyskano moc gazogeneratora rzędu $14885 \mathrm{~kW}$. Uwzględniając, że ok. 0,2\% mocy wytwarzanej w silniku jest przekazywana na napęd centralny, moc jego wyniesie $29,77 \mathrm{~kW}$. Sumując otrzymane moce dla agregatów, otrzymujemy całkowitą moc SNA równą $72,8 \mathrm{~kW}$. Obliczoną wartość mocy przyjęto do dalszych obliczeń dla krytycznego koła zębatego.

Współczynnik tarcia $\mu$ zależy od materiału współpracujących detali oraz rodzaju obciążeń (statyczne lub dynamiczne). Mając na uwadze, że koło zębate jest też obciążone zmęczeniowo, współczynnik tarcia $\mu$ będzie mieścił się w przedziale od 0,09 do 0,03 [2]. Sprawność SNA zmieści się w przedziale od 96,1\% do 98,7\%.

\subsection{Kryterium wytrzymałościowe zębów koła zębatego w SNA}

Przyjęte parametry oraz obliczenia wytrzymałościowe dla koła zębatego przedstawia tab. 4.

\section{Tabela 4}

Parametry wytrzymałościowe dla koła zębatego, źródło: $[17,18]$ oraz dokumentacja WZL

\begin{tabular}{|l|c|c|c|c|c|}
\hline Parametr & $\mathbf{v}$ & $\mathbf{M}_{\mathbf{s}}$ & $\mathbf{M}$ & $\mathbf{F}$ & PMAX \\
\hline Wartość & $27,1 \mathrm{~m} / \mathrm{s}$ & $151,14 \mathrm{Nm}$ & $\geq 2,076 \mathrm{~mm}$ & $2686,9 \mathrm{~N}$ & $1090,91 \mathrm{MPa}$ \\
\hline
\end{tabular}

Przekształcając twardość ze skali Rockwella $\mathrm{C}$ na skalę Brinella, otrzymamy przedział wartości od $287 \mathrm{HB}$ do $372 \mathrm{HB}$ [16]. Współczynnik w, występujący w mianowniku wzoru (16), wyznacza się metodą interpolacji liniowej z tabeli w zależności od wartości prędkości obrotowej i żądanego czasu pracy [11]. W produkcji koła zębatego stosowany jest proces nawęglania zębów, w ramach którego utwardza się powierzchniowo zęby na drodze dyfuzyjnego nasycania (grubość warstwy 0,2 mm), na skutek czego twardość powierzchni zębów wzrasta do 60-64 HRC [5]. Przedział dopuszczalnych nacisków powierzchniowych (16) ulegnie wtedy zmianie $[11,16]$. W tab. 5 zawarto obliczenia skrajnych dopuszczalnych nacisków powierzchniowych.

\section{Tabela 5}

Parametry wytrzymałościowe dla koła zębatego, źródło: [5, 11, 16] oraz dokumentacja WZL

\begin{tabular}{|l|c|c|c|c||}
\hline Parametr & $\mathbf{w}$ & $\mathbf{T}$ & KoMIN & KoMAx \\
\hline Wartość & 2,964 & $1600 \mathrm{~h}$ & $1096,47 \mathrm{MPa}$ & $1214,57 \mathrm{MPa}$ \\
\hline
\end{tabular}




\subsection{Kryterium wytrzymałościowe wielowypustu koła zębatego skrzynki napędów agregatów}

Dopuszczalne naciski powierzchniowe dla połączenia wielowypustowego $K_{d}$, wykonanego ze stali 12H2NWFA-WD, wynoszą $441 \mathrm{MPa}$ [5]. Podstawiając do wzoru (14) dane konstrukcyjne otrzymamy wartość teoretycznych nacisków powierzchniowych na wielowypuście: $F=18659,15 \mathrm{~N}$ i $p=43,56 \mathrm{MPa}$. Teoretycznie wielowypust nie powinien ulegać uszkodzeniu w eksploatacji SNA. Uzyskane wyniki obliczeń wytrzymałościowych nie odwzorowują problemów eksploatacyjnych wielowypustów.

\section{Podsumowanie i wnioski}

Na podstawie przeprowadzonych obliczeń wytrzymałościowych dla oryginalnego materiału koła zębatego i parametrów obróbki cieplno-mechanicznej stwierdzono, że oryginalne koło zębate 380600019 skrzynki napędu agregatów spełnia warunki wytrzymałościowe zębów na zginanie oraz wielowypustu na naciski powierzchniowe. Warunek wytrzymałości zębów na naciski powierzchniowe jest spełniony po ich nawęglaniu powierzchniowym warstwą o grubości $0,2 \mathrm{~mm}$.

Uzyskane pozytywne wyniki obliczeń wytrzymałościowych oryginalnego koła zębatego 380600019 skrzynki napędu agregatów nie odwzorowują problemów zmęczeniowych obserwowanych na polskim zamienniku tego koła zębatego. Zamiennik ulega licznym uszkodzeniom, co może wynikać z: odmienności parametrów mechanicznych używanego materiału (składu chemicznego, mikrostruktury, klasy czystości); jakości obróbki cieplno-chemicznej oraz wpływu naprężeń własnych. Jednoznaczna identyfikacja przyczyny wymaga dalszych badań, w ramach których możliwe będzie też matematyczne oszacowanie trwałości koła zębatego i wałka skrętnego na podstawie obecnych warunków technicznych, a także dostępnych metod szacowania trwałości [21] i wybranych metod badań nieniszczących [8].

Najwięcej problemów eksploatacyjnych dotyczących zamiennika koła zębatego obserwuje się na wielowypuście, gdzie warunek wytrzymałościowy dla oryginalnego koła zębatego jest spełniony $\mathrm{z}$ bardzo dużym zapasem. Bardzo częstymi problemami są zużycie ścierno-korozyjne i przegrzania, na które wpływ mają: 
a) parametry warstwy galwanicznej (oksydowanie, oksydofosforowanie) zmniejszającej tarcie w parze kinematycznej i zwiększające ich odporność na korozję,

b) parametry smarowania i chłodzenia tego połączenia kinematycznego.

Te parametry zostały pominięte $\mathrm{w}$ pierwszym etapie badań problemu eksploatacyjnego i w niniejszym artykule.

Koło zębate i wałek skrętny są wykonane z materiału ferromagnetycznego, co umożliwia zastosowanie współczesnych metod magnetycznych i elektromagnetycznych do nieniszczącej kontroli jakości materiału i stanu technicznego krytycznych elementów [10].

\section{Literatura}

1. Bagiński A., Kułaszka A., Szczepankowski A., Szymczak A.: The diagnosing of turbines of turbomachinery with a visual non-destructive method. Journal of KONBiN 1(17) 2011.

2. fizyka.edu.pl - współczynniki tarcia.

3. gasturb.de - program „GasTurb13”.

4. geology.com/minerals/graphite.shtml - graphite.

5. GOST 11268-76, rosyjska norma państwowa.

6. Karczewski M., Walentynowicz J.: Wpływ mieszanin paliwa F-34 z biokomponentami na osiągi silnika $\mathrm{z}$ zasobnikowym układem wtryskowym. Biuletyn WAT vol. LIX, nr 1, 2010.

7. Mike J., Wesołowski J.: Samolot MIG-29. Opis techniczny. Malbork 2005.

8. ndt.net/search/docs.php3.

9. Ochęduszko K.: Koła zębate. Wyd. Naukowo-Techniczne, Warszawa 1985.

10. Roskosz M., Witoś M., Zieja M.: Examination of Technical Gear with the Help of Magnetic Passive Observer Status. Poster in the 11th European Conference on NonDestructive Testing, 6th-10th October 2014, Prague, Czech Republic.

11. Rutkowski A.: Części maszyn. Wyd. WSIP, Warszawa 1992.

12. Sałaciński M., Stefaniuk M., Synaszko P., Lisiecki J.: Use of a composite repair parches to repair the upper air intake flap for the MiG-29 aircraft engine. Aviation Advances \& Maintenance, Vol. 40, Iss. 2, DOI 10.1515/afit-2017-0010.

13. Stryczek S.: Napęd hydrostatyczny. Tom 1, Wyd. Naukowo-Techniczne, Warszawa 1990.

14. Trelka M., Bartoszewicz J., Urbaniak J.: Selected problems of RD-33 engine Reliability in operation. Combustion Engines, 2016.

15. Witoś, M., Zieja, M., Szczepankowski, A., Szymczak, J.: Structural health monitoring of aero-engines in non-stationary operations. Applied Condition Monitoring 9, Gliwice 2016. 
16. www.cogne.com - Hardness tables, "the conversion between $\mathrm{HB}-\mathrm{HV}-\mathrm{HRC}-\mathrm{HRB}$ Hardness".

17. www.gov.pl/web/obrona-narodowa.

18. www.klimov.ru.

19. www.pkm.edu.pl - obliczanie połączeń wielowypustowych.

20. www.samoloty.pl - encyklopedia lotnicza, samolot MIG-29.

21. Zieja M., Ważny M., Stępień S.: Outline of a method for estimating the durability of components or device assemblies while maintaining the required reliability level. Eksploatacja i Niezawodność - Maintenance and Reliability, 20(2), 2018. 